\title{
$\bullet$ \\ Dynamics of Infectivity and Fatality of COVID-19 Pandemic
}

\author{
IJCRR \\ Section: Healthcare \\ ISI Impact Factor \\ (2019-20): 1.628 \\ IC Value (2019): 90.81 \\ SJIF (2020) $=7.893$ \\ (c) (7) (3) \\ Copyright@IJCRR
}

Abdur Rashid Ahmed

Assistant Professor, Department of Economics, Assam Don Bosco University, Tapesia Gardens, Sonapur, Assam-782402 (lndia)

\section{ABSTRACT}

Introduction: There is much debate about the growing incidence and fatality of COVID-19 in the entire globe that whether this incidence and fatality of the pandemic are really and statistically varying among the countries particularly with different health status and economic development.

Objective: Based on the above research problem, the paper investigates the variations in average death, infection rate, fatality rate and mortality rate and looks into the statistical significance of their growth trends among different group of countries.

Methods: The data on total confirmed cased and the total number of death for 178 countries used in this research has been collected from the World Health Organization (WHO) Coronavirus Disease (COVID-19) Dashboard. The paper explains the current status estimating of average death, incidence rate, fatality rate and mortality rate. Moreover, the paper also investigates the statistical significance of average death, incidence rate, fatality rate and mortality rate applying compound monthly growth rate and one-way ANOVA.

Results: The paper reveals that average death and infection rate of COVID-19 in all countries are increasing irrespective of economic and other categories. However, the fatality rate is found to be very low in relatively low level-income countries as well as low human developed countries. Moreover, one-way ANOVA results also show that infection and mortality rates are significantly very high among high-income countries and high Human Development Index (HDI) level countries. But fatality rate which is significantly high among low-income countries and very low among Global Health Security (GHS) least-prepared countries.

Conclusion: The average death and infection rate of COVID-19 in all countries are increasing irrespective of economic and other categories but the fatality rate is found to be very low in relatively low level-income as well as low HDI level countries.

Key Words: COVID-19, Fatality rate, Mortality rate, Compound monthly growth rate

\section{INTRODUCTION}

The unexpected emergence and expansion of SARS-CoV-2 (Severe Acute Respiratory Syndrome Coronavirus-2) have changed much of the present world in the beginning few months of the year 2020. This is an unprecedented pandemic the world has ever faced when no country across the globe remained unaffected by the disease. SARS-CoV-2 or simply known as COVID-19 is a viral and infectious disease which is newly discovered in China (Wuhan city) in December of 2019. The Government of China officially reported it to WHO on December 31, 2019. Later, the WHO declared the COVID-19 outbreak is a global health emergency on January 30, 2020, and subsequently it was de- clared as a global pandemic on March 11, 2020. After the H1N1 influenza pandemic of 2019, COVID-19 has been given such tag by WHO. According to WHO, there have been 22,256,219 confirmed cases of COVID-19 including 782,456 deaths (fatality rate of $3.5 \%$ ) reported as of 20 August 2020 globally. ${ }^{1}$ Hence, COVID-19 has become a greater threat to the existence of entire humanity and posed a major cause of ongoing economic depression across the globe. However, the major brunt of the pandemic will be borne by the poor countries like sub-Saharan African countries where the medical facilities are not easily available for the poor people and these lower-income or lower-middleincome countries neither have many resources nor have the scientific capacity to contain the spread of COVID- $19 .{ }^{2}$

\section{Corresponding Author:}

Abdur Rashid Ahmed, Assistant Professor, Department of Economics, Assam Don Bosco University, Tapesia Gardens, Sonapur, Assam-782402 (India)

ISSN: 2231-2196 (Print)

ISSN: 0975-5241 (Online)

Received: 05.09 .2020

Revised: 10.10 .2020

Accepted: 29.11 .2020

Published: 03.03 .2021 
According to WHO, most of the COVID-19 infected patients will experience mild to moderate respiratory illness and recover without requiring special treatment. But COVID-19 can be manifested fatal with the presence of co-morbidities and higher risk for aged people or older section of population those with underlying medical problems like cardiovascular disease, diabetes, chronic respiratory disease, and cancer are more likely to develop serious illness. ${ }^{3}$ Currently, there are no proven treatments for COVID-19. However, the whole scientific community especially virologists are busy with many clinical trials and researches evaluating potential treatments of the pandemic. A slew of such studies already has shared the facts and findings of their ongoing researches and clinical trials. Within such a short period, scientists and researchers have found several facts and findings of the emergence and pathogenicity of COVID-19. According to WHO, the COVID-19 virus spreads primarily through tiny droplets and aerosols from the nose when an infected and inattentive person coughs or sneezes. ${ }^{4}$ The spread of this zoonotic disease can be reduced on certain weather conditions like high temperature and humidity which may help to contain the spread of COVID-19 some countries with these weather conditions. ${ }^{5}$ The select preliminary studies while attempting to estimate the pattern of the spread of COVID-19 finds that this virus replicates very fast as like the SARS-CoV-1 (Severe Acute Respiratory Syndrome Coronavirus-1) and the Middle East Respiratory Syndrome coronavirus (MERS$\mathrm{CoV}){ }^{6}$

However, there is a much debate about the growing incidence and fatality of COVID-19 in the entire globe that whether this incidence and fatality of the pandemic are significantly varying among the countries particularly with different health status and economic development. Seeking the answer to this question, the paper investigates the variations in average death, infection rate, fatality rate and mortality rate of 178 countries.

\section{MATERIALS AND METHODS}

\section{Data and Sources}

The data on total confirmed cased and the total number of death for 178 countries used in this research has been collected from the WHO Coronavirus Disease (COVID-19) Dashboard. ${ }^{7}$ However, the various country classifications of these countries have been carried out based on WHO region, Income classification, HDI classification and GHS classification provided by WHO, World Bank, United Nations Development Program, and Global Health Security Index respectively. The Global Health Security (GHS) Index is a comprehensive assessment of health security and related ca- pabilities and it is a jointly developed by the Nuclear Threat Initiative (NTI) and the Johns Hopkins Center for Health Security (JHU) with the help of the Economist Intelligence Unit (EIU).

\section{Statistical Tools}

To analyze the data, I have used simple statistical tools like infection rate, fatality rate, mortality rate, compound monthly growth rate and ANOVA (Analysis of Variance). ${ }^{8}$ Infection, fatality and mortality rates indicate total confirmed cases per million populations, total deaths per million confirmed cases and total deaths per million populations respectively calculated using the following formulas.

i) Infection rate $=\frac{\text { Total confirmed cases of COVID19 }}{\text { Total populations of the country }} \times 1,000,000$

ii) $\quad$ Fatality rate $=\frac{\text { Total deaths in COVID19 }}{\text { Total confirmed cases in the country }} \times 1,000,000$

iii) Mortality rate $=\frac{\text { Total deaths in COVID19 }}{\text { Total populations of the country }} \times 1,000,000$

iv) The compound monthly growth rate $(\mathrm{CMGR})=\left(\frac{\text { Value of current month }}{\text { Value of the base month }}\right)^{\frac{1}{n-1}}-1$

Also, ANOVA (Analysis of Variance) has been applied to test variation of the infection rate, fatality rate, mortality rate among the various country groups.

\section{RESULTS AND DISCUSSION}

\section{Spread and Status}

The spreading out of COVID-19 and current status of the pandemic has been discussed with the help of an average number of death, infection rate (number of confirmed cases per million populations), fatality rate (number of deaths per million confirmed cases) and mortality rate (number of deaths per million populations) as defined in the methodology. ${ }^{9}$

Table-1 displays the average death, infection, fatality and mortality rates of COVID-19 pandemic in different geographical regions. ${ }^{10}$ This table shows that infection rate and mortality rate are highest in South American countries whereas the fatality rate is very high in European countries. In contrast, more specifically as per World Bank classification, East and South Asian countries show having very less infection, fatality and mortality rates compared to European and North American countries. 
Table 1: Infection, Fatality and Mortality rates of COVID-19 by Geographical Regions

\begin{tabular}{|c|c|c|c|c|c|}
\hline Region/Country & $\begin{array}{l}\text { Average } \\
\text { Death }^{1}\end{array}$ & $\begin{array}{c}\text { Infection } \\
\text { Rate }^{2}\end{array}$ & $\begin{array}{c}\text { Fatality } \\
\text { Rate }^{3}\end{array}$ & $\begin{array}{l}\text { Mortality } \\
\text { Rate }^{4}\end{array}$ & $\mathbf{N}$ \\
\hline \multicolumn{6}{|l|}{ By Continent } \\
\hline Asia & 2710 & 4511 & 16106 & 40 & 41 \\
\hline Europe & 4746 & 4082 & 44845 & 186 & 44 \\
\hline Africa & 457 & 1064 & 28102 & 18 & 53 \\
\hline North America & 10376 & 3233 & 25345 & 99 & 23 \\
\hline South America & 14283 & 7263 & 29929 & 251 & 12 \\
\hline Oceania & 81 & 240 & 17190 & 4 & 5 \\
\hline \multicolumn{6}{|l|}{ By World Bank Classification } \\
\hline East Asia \& Pacific & 800 & 746 & 17181 & 5 & 19 \\
\hline Europe \& Central Asia & 4338 & 3984 & 41947 & 175 & 49 \\
\hline South Asia & 7536 & 2151 & 12767 & 21 & 8 \\
\hline Latin America \& Caribbean & 7122 & 4321 & 25328 & 138 & 33 \\
\hline Middle East \& North Africa & 1941 & 7393 & 32312 & 60 & 20 \\
\hline Sub-Saharan Africa & 376 & 1015 & 22950 & 17 & 47 \\
\hline North America & 87505 & 9459 & 53131 & 370 & 2 \\
\hline \multicolumn{6}{|l|}{ By WHO Classification } \\
\hline South East Asian Region & 5884 & 1551 & 12226 & 12 & 10 \\
\hline Eastern Mediterranean Region & 2258 & 6863 & 35927 & 58 & 20 \\
\hline African Region & 388 & 1027 & 22326 & 17 & 47 \\
\hline American Region & 11715 & 4615 & 26917 & 151 & 35 \\
\hline European Region & 4180 & 4069 & 40594 & 170 & 51 \\
\hline Western Pacific Region & 608 & 907 & 16563 & 5 & 15 \\
\hline Total & 4239 & 3279 & 28938 & 90 & 178 \\
\hline
\end{tabular}

Notes: 'Average Death shows absolute number (rounded off).

${ }^{2}$ Infection rates indicate Cases per million populations.

3Fatality rates show Deaths per million cases.

${ }^{4}$ Mortality rates indicate Deaths per million populations.

$\mathrm{N}$ is total number of observations (i.e. countries)

Source: Author's Calculation based on 178 countries collected from WHO.

However, Table-2 exhibits the infection, fatality and mortality rates of COVID-19 among countries with different level of economic development. The table demonstrates that infection, fatality and mortality rates are significantly very lofty among high and upper-middle-income countries (i.e. countries with GNI per capita greater than US\$3996) whereas low-income countries (i.e. countries with GNI per capita less than US\$1026) register low infection and mortality. Moreo- ver, classification by HDI (Human Development Index) shows that countries with very high and high human development are having the soaring infection, fatality and mortality rates. ${ }^{11}$ Similarly, the countries with high Global Health Security Index (GSHI) grouped as most prepared countries (i.e. countries with overall GHS Index of 66 or greater out of 100) are also register high infection, fatality and mortality rates compared to more and least prepared countries.

Table 2: Infection, Fatality and Mortality rates of COVID-19 by Economic Category

$\begin{array}{lcccc}\text { Region/Country } & \begin{array}{c}\text { Average } \\ \text { Death }\end{array} & \begin{array}{c}\text { Infection } \\ \text { rate }\end{array} & \begin{array}{c}\text { Fatality } \\ \text { rate }\end{array} & \begin{array}{c}\text { Mortality } \\ \text { rate }\end{array} \\ \text { By Income Classification (based on GNI per capita) } & & & \\ \text { High income (>12,375 US\$) } & 6582 & 5550 & 37460 & 160 \\ \text { Upper middle income } & 5956 & 3827 & 22981 & 103\end{array}$

$(3,996$ US\$-12,375 US\$) 
Table 2: (Continued)

\begin{tabular}{|c|c|c|c|c|c|}
\hline Region/Country & $\begin{array}{l}\text { Average } \\
\text { Death }\end{array}$ & $\begin{array}{l}\text { Infection } \\
\text { rate }\end{array}$ & $\begin{array}{l}\text { Fatality } \\
\text { rate }\end{array}$ & $\begin{array}{l}\text { Mortality } \\
\text { rate }\end{array}$ & $\mathbf{N}$ \\
\hline $\begin{array}{l}\text { Lower middle income } \\
(1,026 \text { US\$-3,996 US\$) }\end{array}$ & 1837 & 1576 & 19651 & 38 & 45 \\
\hline Low income $(<1,026$ US\$) & 179 & 330 & 37237 & 8 & 27 \\
\hline \multicolumn{6}{|c|}{ By Human Development Classification (based on HDI Score) } \\
\hline $\begin{array}{l}\text { Very High Human Development } \\
(>=0.800)\end{array}$ & 6719 & 5568 & 36342 & 155 & 60 \\
\hline $\begin{array}{l}\text { High Human Development (o.70o- } \\
\text { o.799) }\end{array}$ & 5328 & 3505 & 23226 & 102 & 51 \\
\hline $\begin{array}{l}\text { Medium Human Development (o.550- } \\
\text { o.699) }\end{array}$ & 2364 & 1719 & 19041 & 40 & 31 \\
\hline Low Human Development $(<0.550)$ & 178 & 488 & 33212 & 10 & 36 \\
\hline \multicolumn{6}{|c|}{ By Global Health Security Classification (based on GHS Index Score) } \\
\hline Most Prepared (>66.6) & 20163 & 3794 & 61003 & 245 & 13 \\
\hline More Prepared (33.4-66.6) & 4614 & 4323 & 26888 & 106 & 103 \\
\hline Least Prepared $(<33.4)$ & 277 & 1437 & 25620 & 32 & 62 \\
\hline Total & 4239 & 3279 & 28938 & 90 & 178 \\
\hline
\end{tabular}

Source: Author's Calculation based on 178 countries collected from WHO.

\section{Growth of infection and fatality}

The current status discussed in the above tables is silence about the trend of the COVID-19 i.e. whether it is growing or shrinking in the different regions. Hence, to capture the aspects I have applied compound monthly growth rate (using a similar method of calculating compound annual growth rate, CAGR). The compound monthly growth rate (CMGR), estimated for February-July of 2020, will help us to track the growth of COVID-19 pandemic in terms the average number of death, infection rate, fatality rate and mortality rates among the countries with different level of health-related and economic development has been shown in the following table and panels. ${ }^{12,13}$
Table-3 displays that average death and infection rate of COVID-19 in all continents are increasing at an alarming rate but unlike in other continents, the fatality rate in Asia and Africa registers a decreasing trend. In a similar vein, average death and infection rate of COVID-19 in all countries irrespective of economic and other categories are increasing whereas the fatality rate in relatively low-level income countries (lower-middle and low-income countries) and or low human development countries, it is declining. Moreover, the least prepared countries in GHS index also shows declining fatality rate.

Table 3: Compound monthly growth rate (CMGR) of Average Death, Infection, Fatality and Mortality rates (Estimated for February-July 2020 period)

$\begin{array}{lcccc}\text { Region/Country } & \text { Average Death } & \text { Infection rate } & \text { Fatality rate } & \text { Mortality rate } \\ \text { By Continent } & & & & \\ \text { Asia } & 89.8 & 172.3 & -7.1 & 122.4 \\ \text { Africa } & 244.7 & 227.6 & -5.5 & 210.3 \\ \text { Europe } & 61.4 & 51.8 & 17.3 & 67.5 \\ \text { North America } & 201.2 & 143.4 & 7.8 & 204.8 \\ \text { South America } & 411.1 & 250.3 & 3.0 & 377.6 \\ \text { Oceania } & 81.5 & 32.3 & 68.3 & 90.7\end{array}$


Table 3: (Continued)

\begin{tabular}{lcccc} 
Region/Country & Average Death & Infection rate & Fatality rate & Mortality rate \\
By GHS Index Category & & & & \\
Most Prepared & 127.7 & 63.4 & 22.5 & 92.9 \\
More Prepared & 89.7 & 100.3 & 2.6 & 91.3 \\
Least Prepared & 212.4 & 85.2 & -1.5 & 79.9 \\
& & & & \\
By Income Category & 81.3 & & & 71.3 \\
High income & 142.2 & 71.5 & 20.7 & 173.6 \\
Upper middle income & 284.3 & 172.1 & 0.8 & 268.4 \\
Lower middle income & 234.2 & 263.5 & -9.9 & 231.1 \\
Low income & & 263.7 & -3.9 & \\
& & & & 71.9 \\
By HDI Category & 83.9 & 73.7 & 20.0 & 174.1 \\
Very High Human Development & 138.6 & 166.3 & 1.6 & 256.4 \\
High Human Development & 333.2 & 305.4 & -17.6 & 277.3 \\
Medium Human Development & 257.2 & 259.7 & 0.6 & \\
Low Human Development & & & & \\
\hline
\end{tabular}

Source: Author's Calculation based on 178 countries collected from WHO.

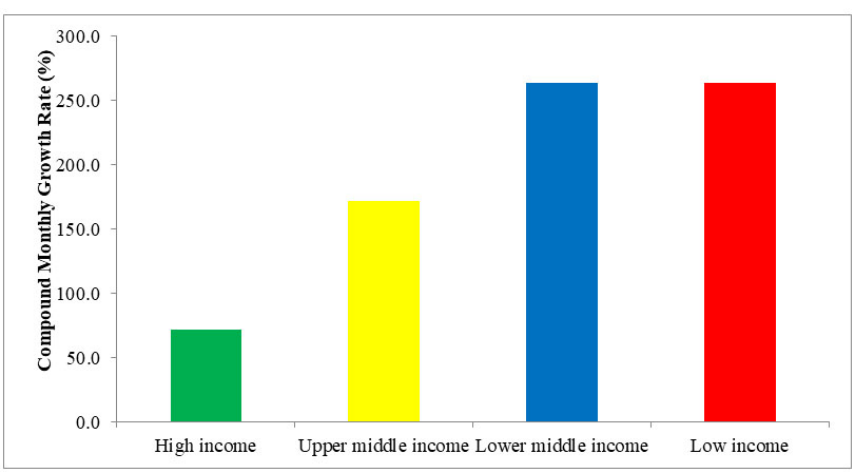

Figure 1: Growth of Infection in different Income countries (During February-July 2020).

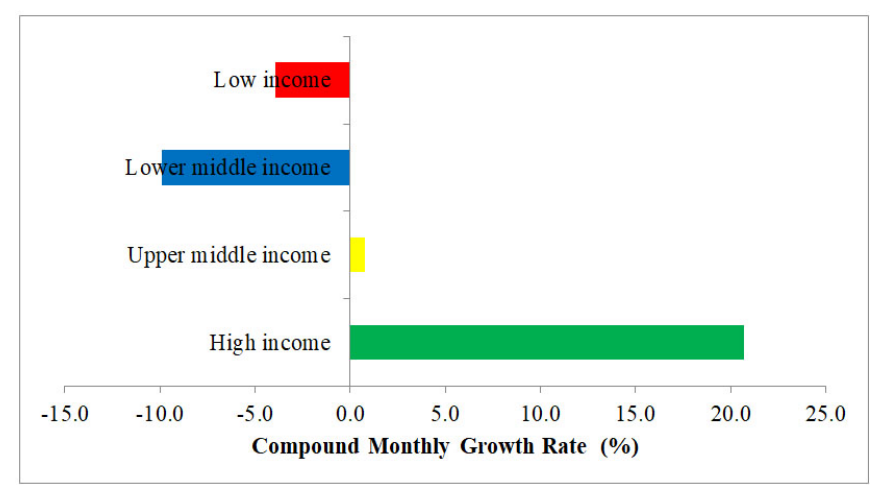

Figure 2: Fatality in different Income countries (During February-July 2020).

\section{Results of one-way ANOVA}

But the variations of the numbers observed in the above tables may be random and we can't say with certainty and conviction that the variations are statistically significant in terms of infection, fatality and mortality rates among the countries/ regions or countries with different level of economic development without formal confirmation with statistical analysis.

Table 4: One-way ANOVA Outputs

\begin{tabular}{llcl}
$\begin{array}{l}\text { Dependent } \\
\text { Variable }\end{array}$ & $\begin{array}{l}\text { Independent } \\
\text { Variable } \\
\text { (Group Variable) }\end{array}$ & F-Statistic & P-value \\
Infection rate & Continents & $4 \cdot 74^{* * *}$ & 0.0004 \\
& Income Group & $9 \cdot 37^{* * *}$ & 0.0000 \\
& HDI Group & $9 \cdot 34^{* * *}$ & 0.0000 \\
Fatality rate & GHS Index Group & $6.31^{* * *}$ & 0.0023 \\
& Continents & $3.78^{* * *}$ & 0.0028 \\
& Income Group & $3.75^{* *}$ & 0.0120 \\
& HDI Group & $2.75^{* *}$ & 0.0444 \\
Mortality rate & GHS Index Group & $7.17^{* * *}$ & 0.0010 \\
& Continents & $11.56^{* * *}$ & 0.0000 \\
& Income Group & $8.67^{* * *}$ & 0.0000 \\
& HDI Group & $8.35^{* * *}$ & 0.0000 \\
& GHS Index Group & $12.02^{* * *}$ & 0.0000 \\
\hline
\end{tabular}

Notes: ***Very highly significant, ${ }^{* *}$ Highly Significant \& *Significant

Source: Author's Calculation (see Appendix-2). 
Hence, several one-way ANOVA taking infection rate, fatality rate and mortality rate as the dependent variable to test them among different continents, income group, HDI group and GHS index group as independent variables (as shown in Table-4). The results show that infection and mortality rates are significantly very high among countries with high-income as well as with high HDI level. But the fatality rate is significantly high among low-income countries (see Table-2). Besides, the fatality rate is also significantly low among the least-prepared countries as classified by the GHS index. ${ }^{14}$

\section{CONCLUSION}

The paper investigates that whether the incidence, fatality and mortality of COVID-19 pandemic are really and statistically varying among the countries particularly with different health status and economic development. The paper reveals that the variations in average death, infection rate, fatality rate and mortality rate irrespective of economic and other categories are increasing significantly. The results also corroborated by the one-way ANOVA analysis which reconfirms that infection and mortality rates are significantly very high among high-income and high HDI level countries. But, the results also show that the fatality rate is significantly lowincome countries as well as among the GHS least-prepared countries. However, a host of scientists working on various preventive measures to reduce the fatality rate of COVID-19. But the potential gains from these upcoming preventive strategies should incorporate the necessary precautions of economic and health consequences of that future preventive measures. ${ }^{15}$

Author Contributions: All works regarding conceptualization, development of methodology, original draft preparation, review and editing etc. all carried out by the author.

\section{ACKNOWLEDGEMENT}

Authors acknowledge the immense help received from the scholars whose articles are cited and included in references to this manuscript. The authors are also grateful to authors/ editors/publishers of all those articles, journals and books from where the literature for this article has been reviewed and discussed.

Conflict of Interest: Nil

Source of Funding: Nil

Ethical Approval: Not Applicable

\section{REFERENCES}

1. WHO. Coronavirus disease 2019 (COVID-19) Situation Report-46. 2020 [Available at: https://www.who.int/emergencies/ diseases/novel-coronavirus-2019/situation-reports].

2. Alimoglu O, Kilic F, Erol CI, Eren T. What the COVID-19 pandemic means for sub-Saharan African countries. Int J Human Health Sci 2020;5(1):127-128.

3. Huang C, Wang Y, Li X, Ren L, Zhao J, Hu Y, et al. Clinical features of patients infected with 2019 novel coronavirus in Wuhan, China. Lancet 2020;395(10223).

4. WHO. Global surveillance for COVID-19 caused by human infection with COVID-19 virus. 2020. Available at [https:// www.who.int/publications/i/item/global-surveillance-for-covid19-caused-by-human-infectionwith-covid-19-virus-interimguidance]

5. Colapkulu N, Simsek FI, Leblebici IM, Alimoglu O. Covid-19 pandemic and weather conditions: Can temperature curb the spread? Int J Human Health Sci 2020;5(2):264-266.

6. Jie S, Logeswaran R. Estination of the Basic Reproduction Rate $\left(\mathrm{R}_{0}\right)$ of the Novel Coronavirus (COVID-19). Int J Curr Res Rev 2020;12(20):81-86.

7. WHO. Coronavirus Disease (COVID-19) Dashboard. August 2020, Available at [https://covid19.who.int/]

8. Ghani AC, Donnelly CA, Cox DR, Griffin JT, Fraser C, Lam TH, et al. Methods for estimating the case fatality ratio for a novel, emerging infectious disease. Am J Epidemiol 2005;162:479486.

9. Angelopoulos A, Pathak R, Varma R, Jordan MI. Identifying and Correcting Bias from Time- and Severity- Dependent Reporting Rates in the Estimation of the COVID-19 Case Fatality Rate. Harvard Data Sci Rev 2020. https://doi.org/10.1162/99608f92. f01ee285

10. Public Health Agency of Sweden. The infection fatality rate of COVID-19 in Stockholm-Technical report. 2020, Available at https://www.folkhalsomyndigheten.se/contentassets/53c0dc3 91be54f5d959ead9131 edb771/infection-fatality-rate-covid19stockholm-technical-report.pdf]

11. UNDP. Human Development Report: Overcoming Barriers: Human Mobility and Development. 2009. Available at http://hdr. undp.org/en/reports/global/hdr2009/]

12. Sharma A, Tiwari S, Deb MK, Marty JL. Severe acute respiratory syndrome coronavirus-2 (SARS-CoV-2): a global pandemic and treatment strategies, Int J Antimicrob Agents 2020;56(2):106054.

13. Zhou F, Yu T, Du R. Clinical course and risk factors for mortality of adult inpatients with COVID-19 in Wuhan, China: A Retrospective Cohort Study. The Lancet. 2020; 395 (10229):1054-1062.

14. Pan D, Sze S, Minhas JS, Bangash MN, Pareek N, Divall P, et al. The impact of ethnicity on clinical outcomes in COVID-19: A systematic review. E Clinical Medicine. 2020;23:100404.

15. Godman, Brian. Combating COVID-19: Lessons learnt particularly among developing countries and the implications. Bangladesh J Med Sci 2020;19:103-108. 